\title{
Bank lending and financial discrimination from the formal economy: How women entrepreneurs get forced into involuntary bootstrapping
}

\author{
Malin Malmström*, Joakim Wincent \\ Department of Economics and Technology and Society, Luleå University of Technology, SE-971 87 Luleå, Sweden
}

\begin{abstract}
A B S T R A C T
The role of banks, their decision models, and their linkages with how entrepreneurs can act as providers to the formal economy have not been focused on much in entrepreneurship research. We explore the trend of transaction-based lending among banks on entrepreneurs' engagement in informal economic activities (or involuntary bootstrapping activities) and how that relationship is moderated by gender. The results show that women entrepreneurs who encounter banks with transaction-based lending are forced to engage in much more informal economic activities compared to men, while this gender bias vanishes when entrepreneurs face banks with relationbased lending. We associate these results with gender stereotyping and suggest transactionbased lending to be costly for the development of formal economies.
\end{abstract}

\section{Introduction}

Banks have been acknowledged as the most important external financiers for entrepreneurs (Berger and Udell, 2006; Black and Strahan, 2002), but they are also important for a well-functioning economy because they align the formal economy with the way in which resources, and thus how entrepreneurs, engage in the development of the welfare in the formal economy (Messner and Rosenfeld, 2001). A change in the distribution of formal economy resources, such as in banks, and their decision models for capital distribution will likely affect the levels of illegal or illegitimate behavior outside the formal economic system (Messner and Rosenfeld, 1997). Indeed, research has argued that the choice to pursue a marginally accepted or illegitimate behavior to achieve an end, such as venturing, is particularly likely when a formal system prevents individuals from achieving their goals (Merton, 1968). One such deviant behavior is involuntary bootstrapping, which may become necessary when entrepreneurs are forced to engage in marginally accepted or illegal financial solutions. We need to explore such a mechanism to determine how formal institutions, and banks specifically, can better include various social categories of individuals in the formal economy and to ensure secure, efficient, and stable formal institutions.

There is a lack of studies focusing on the informal economy from an entrepreneurial perspective (e.g., De Castro et al., 2008; Khavul et al., 2009; Siqueira and Bruton, 2010; Webb et al., 2009), and to our knowledge, only a very limited number of studies have focused on the role of gender in individuals' engagement in deviant behaviors or activities that involve the informal economy. To address this research gap, this article investigates the determinants of banks' decision-making models and gender on entrepreneurs' participation in informal economic activities. We focus on two different lending models in the banking sector to test hypotheses predicting the criterion for women and men entrepreneurs' involuntary engagement in informal economic activities (i.e., financial

\footnotetext{
* Corresponding author.

E-mail addresses: malin.malmstrom@ltu.se (M. Malmström), joakim.wincent@ltu.se (J. Wincent).
} 
bootstrapping activities). We study the effects of the transaction-based lending model, which the majority of banks use when centralizing bank functions. This is the dominant model and current trend in banking and has led many banks to focus on large cities as well as decrease or completely withdraw from local representation. We develop and test a set of arguments suggesting that when formal institutions, such as banks, are not available for entrepreneurs, they have to turn to involuntary bootstrapping and engagements in the informal economy, and that this lack of availability is most pressing for women entrepreneurs.

\section{Literature background}

\subsection{Engaging in informal economic activities as a response to denied access by the formal economy}

We set out to examine the effects of banks' decision-making models on entrepreneurs' engagement in informal economic activities. The informal economy refers to entrepreneurs' use of informal/local economic activities when they have been excluded by formal institutions or are unable to satisfy formal market standards (Sutter et al., 2017; Webb et al., 2014). Such activities occur outside formal institutions and are guided by prescriptions of the informal norms, beliefs, and values underpinning "more-or-less taken-for-granted repetitive social behavior" (Webb et al., 2009) that follows alternative notions of what is socially acceptable and provides alternative structures for economic activity (North, 1990). An increase of entrepreneurs who engage in informal economic activities may highlight problematic consequences of institutional and regulatory changes in the formal economy. By attempting to achieve venture success, such changes may force entrepreneurs to break or depart from formal rules and redefine existing norms and notions. Such deviations may create value, but entrepreneurs will operate outside society's laws and regulations in the informal economy when doing so (Webb et al., 2009). In fact, informal economy activities have been referred to as the underground or shadow economy, describing economic activities that are outside formal institutional boundaries but remain within informal institutional boundaries (Castells and Portes, 1989; Webb et al., 2009). These activities, while on a floating grey scale from legal to illegal and from visible to invisible, often remain legitimate for an entrepreneur and a large portion of an entrepreneur's stakeholders (Rutherford and Buller, 2007; Webb et al., 2009). Entrepreneurs can be required to look for financial solutions outside formal economic institutions when they are denied access to formal financing (Messner and Rosenfeld, 1997). In line with Merton (1968), we posit that deviant behavior can emerge when an entrepreneur lacks access to formal finances, leading the entrepreneur to use informal means to achieve his or her goals.

The activities commonly included in the literature on the informal economy are closely associated with those described in the entrepreneurship literature as bootstrapping (e.g., Carter and Van Auken, 2005; Winborg and Landström, 1997), bricolage strategies (Baker and Nelson, 2005; Garud and Kamoe, 2003), and resource cooptation (Starr and Macmillan, 1990; Westphal et al., 2006). These streams of research share a focus on how entrepreneurs in resource-constrained environments engage in informal economic activities to acquire necessary resources and how-in doing so-they may exploit others' resources (Freear et al., 1995; Malmström, 2014). The act of bootstrapping represents entrepreneurs' responses to encountering obstacles when trying to acquire resources in the formal economy (Bhide, 1992; Vanacker et al., 2011). As venture survival depends on access to finance, bootstrapping provides informal financing alternatives to ventures that lack access to traditional sources of capital (Van Auken and Neeley, 1996). To cope with reduced access to capital, entrepreneurs devise activities that reduce overall capital requirements, improve cash flow, and take advantage of personal sources of financing to acquire essential resources that minimize the amount of outside debt and equity financing needed from banks and investors (Winborg \& Landstrom, 2001). The description of financial bootstrapping captures the grey zone of informal economic activities as these activities range from legal to illegal, legitimate to illegitimate, and visible to invisible. While they are resource-relieving activities, they are also vaguely legal as they may include, for example, forgoing or withholding payments and breaking credit agreements (Webb et al., 2013). Specifically, bootstrapping activities include the use of undocumented workers and trade of services, and tax avoidance, among others (Van Auken, 2003; Ebben and Johnson, 2006; Winborg and Landstrom, 2000). In these ways, bootstrapping includes activities that lay in a grey zone that is linked to illegal and/or illegitimate activities and is aligned with informal economy research (Centeno and Portes, 2006; Portes and Haller, 2005). The informal economy is commonly described as the production of legal goods using processes that are not wholly legal or as unregistered economic activities that produce legal products (Nichter and Goldmark, 2009). It has also been shown that financially constrained ventures generally use all bootstrapping activities and are more likely to use activities that align with illegal and illegitimate activities (Ebben, 2009). When involuntary bootstrapping, which we stress in our study, there is a clear deviation from accepted behaviors, and such activities are clearly the last resort when bank financing is not available.

\subsection{Transaction-based lending: The ticket to informal economy activities}

Relationship lending refers to relying significantly on "soft" qualitative information collected through social relationships between the banker and the entrepreneur/venture. Such information may include the entrepreneur's character and reliability; the venture's payment and receipt history from previous loans or other bank services to the entrepreneur/venture; or the venture's future prospects based on information from the venture's suppliers, customers, or neighboring businesses. As such, assessing entrepreneurial qualities is at the core of relationship-based lending, which enables the banker to monitor the entrepreneur closely and acquire specific information that is only available to the entrepreneur and the bank (Hauswald and Marquez, 2006). In fact, assessing entrepreneurial qualities, such as the entrepreneur's character, experiences, and merits, has been identified as crucial for banks' decision making (e.g., Berger and Udell, 2002). Research has shown that such assessments require social relationships between financiers and entrepreneurs (Baron and Markman, 2003). These social relationships also enable financiers to gain access to 
other "insider information," such as ventures' business models, which are seldom formally documented or expressed in writing (Morris et al., 2005; Shafer et al., 2005; Malmström et al., 2015). Relationship-based lending has been shown to require locally anchored relationships between banks and entrepreneurs (Cotugno et al., 2013; Hauswald and Marquez, 2006). Accordingly, local banks engaging in relationship-based lending will have an information advantage over centralized banks using transaction-based lending.

The centralization of banks in general has made the exchange of information through social relationships impracticable and has led banks to shift to transaction-based lending. Transaction-based lending is dominated by accounting information, credit scoring, and the quality of accessible assets as collateral (Holthausen and Leftwich, 1983), which together require ventures to have highquality assets and financial report analyses specifying their current and historical financial statuses (Berger and Udell, 2002). Such requirements are difficult for new businesses to meet, and the production of high-quality financial reports can be time consuming and expensive for small ventures. As such, it is often difficult for entrepreneurs to produce the information centralized banks need for their decision making. Accordingly, distant relationships between banks and entrepreneurs may potentially increase difficulties in banks' assessments and could result in unnecessarily low access to capital and demanding credit terms, such as high interest rates and a high need for collateral (Gorman et al., 2005). Consistent with Kornhauser (1978), we argue that the lack of access to the formal economy as well as isolation from financial institutions appear to be key factors underlying engagement in informal economic activities. When banks and other institutions form locally based social relationships with entrepreneurs, their capacity to monitor and exercise control increases because they are better able to engage with the entrepreneurs. Thus, local banks and contacts with banks via relationship lending facilitate entrepreneurs' business venturing by formally supporting entrepreneurship and offering opportunities for entrepreneurs to choose their level of engagement in informal economic activities. Based on this reasoning, we offer the following hypothesis:

Hypothesis 1. The greater the extent of banks' relationship-based lending, the less entrepreneurs will engage in involuntary financial bootstrapping activities.

\subsection{Gender stereotyping and access to the formal economy}

Research on women entrepreneur's bootstrapping beyond the topics of personal funding, slowing disbursements, and accelerating collections is scarce (Carter and Van Auken, 2005; Van Auken, 2005; Carter et al., 2003). The limited research on the relationship between gender and bootstrapping has shown that women entrepreneurs bootstrap in all stages of business development when they position their ventures for growth (Brush et al., 2006). Moreover, while men and women entrepreneurs engage in similar bootstrapping activities, the factors affecting the use of bootstrapping may differ between women and men (Neeley \& Van Auken 2010), which associate with women entrepreneurs' greater barriers to accessing financing (Coleman, 2004). Previous studies have shown gender biases in access to finance, revealing that women have lower access to such resources and that when they are approved for financing, they face more demanding credit terms compared to men (Malmström et al., 2017a). The origin of these biases has been linked to stereotyping, which has led men entrepreneurs to be perceived as being more ambitious and having more entrepreneurial potential than women (e.g., Kanze et al., 2017; Malmström et al., 2018; Malmström et al., 2017b). Research has also shown that stereotypes of women and men are automatically activated when a person's gender is identified (Banaji and Hardin, 1996), and thus the problem is the expectations perceivers attach to gender. The activation of gender stereotypes can significantly influence perceptions that an entrepreneur is financeable and can sway decisions to approve or reject loans to women and men entrepreneurs as notions about entrepreneurship interact with male and female stereotypes (Fiske, 2000; Heilman, 2001; Alsos et al., 2006). The bootstrapping literature has demonstrated that in contexts where interactions with banks are rare, bootstrapping may be the only option for entrepreneurs to deal with their financial needs. In such contexts, we may expect women entrepreneurs to encounter even more constraints in terms of access to finance, and as a consequence, they will bootstrap more than men. Thus, we propose the following:

\section{Hypothesis 2. Women entrepreneurs engage in more involuntary financial bootstrapping activities compared to men} entrepreneurs.

The social order of gender and the economic status of local contexts may influence the repertory of available formal financial resources for entrepreneurs and may thus also influence their need to engage in informal economic activities. Therefore, gender provides an "implicit background identity" for a banker when he or she assesses an entrepreneur (Ridgeway, 2001), but this identity may change if the banker meets with the entrepreneur, which research has emphasized is important in lending assessments (Berger and Udell, 2002). With limited interactions between banks and entrepreneurs, background knowledge stemming from stereotypes may frame bankers' perceptions of entrepreneurs, which may be amplified when no actual social interactions occur that could adjust the influence of stereotypes. The presence of stereotypes and the resulting biased evaluations are thus likely when banks use transaction-based lending as those models disregard assessments of entrepreneurial qualities, which are generally collected through social relationships. As such, we expect that women will bootstrap more when banks apply transaction-based lending because such models may allow for stereotypes to influence decision making as the lack of interaction with entrepreneurs hinders adjustment to the entrepreneurs' individual circumstances and potential. At a distance, more gender stereotyping risks being activated, which is in turn associated with more gender-biased lending. In this context, we propose the following explorative question: will more transaction-based lending increase women entrepreneurs' involuntary bootstrapping while decreasing men entrepreneurs' involuntary bootstrapping? 


\section{Method}

This article is based on secondary bank data and a survey that was sent to a random sample of Swedish entrepreneurs applying for bank financing. We received a total of 145 usable answers, which corresponds to a response rate of $24 \%$. The survey was developed on the basis of existing measurements (Chandler and Lyon, 2001).

\subsection{Dependent variable}

\subsubsection{Necessity of bootstrapping activities}

Evidence from prior studies clearly shows the existence of bootstrapping activities. In fact, studies have shown that as many as 80-95\% of small ventures engage in some form of bootstrapping activity although some of these activities may be involuntary and reside in the grey or black zone of what is accepted in the formal economy by important stakeholders and governmental regulations (Freear et al., 1995; Harrison and Mason, 1997; Harrison et al., 2004; Winborg and Landstrom, 2000). To assess what we conceptualized as the extent of necessity of engaging in bootstrapping activities and thus to obtain an indication of this involuntary behavior among entrepreneurs, we used a set of questions drawing on items from Winborg and Landström (1997) asking the respondents/entrepreneurs to rate the "degree of being forced/necessity" on a seven-point Likert scale ( 1 = very low necessity; $7=$ very high necessity). We presented a list of 20 various items related to necessary engagement in bootstrapping activities, for example, avoiding and postponing paying taxes and not paying invoices. Bootstrapping was thus measured as a composite of these items. The Cronbach's alpha $(\alpha)$ was 0.827.

\subsection{Independent and moderating variables}

\subsubsection{Banks' decision models}

Using a seven-point Likert scale (1 = do not agree at all; 7 = completely agree) and inspired by Berger and Udell (2002, 2006) and Beck and Demirguc-Kunt (2006), we asked the respondents/entrepreneurs about the possibility of utilizing bank relationships to provide them with information in the areas of products/services, financial situations, and ways to keep the business going. An example item is "To what extent are your bank relationships important when you face a problem regarding the venture's financial situation that you cannot cope with by yourself?" Relationship-based models were measured as a composite of these items $(\alpha=0.748)$. The composite was multiplied categorizing the models to the context of banks with transaction-based/centralized decision-making models based on bank secondary information. This measure range from a centralized/transaction-based model (low values) to a decentralized/relation-based model (high values).

\subsubsection{Gender of the entrepreneur}

A value of 1 indicated male applicant entrepreneurs, and a value of 0 indicated female applicant entrepreneurs. We tested the impact of gender on the dependent variable (i.e., necessity of bootstrapping activities).

\subsection{Control variables}

\subsubsection{Capital need}

We controlled for capital need, which is consistent with the studies of O'Gorman and Terjesen (2006) and Haynes and Haynes (1999), who found that women and men entrepreneurs have similar funding requirements in terms of the total volume of investment required. In addition, studies have shown that entrepreneurs bootstrap more when they are in higher need of capital (Van Auken, 2005; Ebben and Johnson, 2006). Capital need was measured as a composite of two items: the perceived extent of capital needed for the business to develop according to plan and for the business to run without encountering obstacles (i.e., to sustain production levels or avoid payment difficulties) $(\alpha=0.791)$

\subsubsection{Venture age}

We controlled for venture age, measured as the number of years the business had been actively operating, in line with who posited that a venture's age influences its ability to repay loans. In addition, previous studies on bootstrapping show that young ventures rely more on bootstrapping compared to older ventures (Vanacker et al., 2011; Winborg, 2009).

\subsubsection{Venture size}

We controlled for the size of the venture, measured as the number of employees. Different types of bootstrapping have been observed at different growth stages in small ventures (Ebben and Johnson, 2006).

\subsubsection{Educational level of the entrepreneur}

We controlled for the educational level of the entrepreneur. Highly educated entrepreneurs have been viewed as being more aware of financial processes, sources of finance, and the importance of exploring financial alternatives. Moreover, scholars have argued that a higher education also reduces an individual's willingness to justify unethical behaviors (Chamlin and Cochran, 1995; Messner and Rosenfeld, 2001) as educational systems transmit values that discourage egoism, endorse respect for others, and 
Table 1

Means, standard deviations, and correlations.

\begin{tabular}{|c|c|c|c|c|c|c|c|c|c|c|}
\hline & Mean & Std. Deviation & 1 & 2 & 3 & 4 & 5 & 6 & 7 & 8 \\
\hline Age of the firm (years) & 24.14 & 26.44 & 1 & & & & & & & \\
\hline Number of employees & 16.26 & 24.89 & $0.176^{*}$ & 1 & & & & & & \\
\hline Educational level of CEO & 3.63 & 1.44 & 0.062 & 0.096 & 1 & & & & & \\
\hline Educational level of employees & 4.34 & 1.39 & -0.109 & -0.003 & $0.594 * *$ & 1 & & & & \\
\hline Capital need & 2.39 & 1.41 & -0.116 & -0.002 & 0.082 & 0.000 & 1 & & & \\
\hline Gender & 0.83 & 0.38 & -0.046 & 0.013 & -0.136 & 0.020 & $-0.253^{* *}$ & 1 & & \\
\hline Banks transaction/relation model dominance & 6.01 & 3.45 & -0.024 & -0.153 & -0.144 & $-0.210^{*}$ & $0.400^{* *}$ & $-0.315^{* *}$ & 1 & \\
\hline necessity to bootstrap & 1.76 & 0.74 & -0.093 & -0.025 & 0.060 & -0.062 & $-0.343^{* *}$ & $-0.268 * *$ & -0.046 & 1 \\
\hline
\end{tabular}

Notes. Reliability indices ( $\alpha$ ) are displayed in parentheses on the diagonal.

Correlation is significant at the 0.10 level (two-tailed). ${ }^{\dagger} p<0.10$.

Correlation is significant at the 0.05 level (two-tailed). ${ }^{*} p<0.05$.

Correlation is significant at the 0.01 level (two-tailed). ${ }^{* *} p<0.01 *$.

promote the rejection of crime (Van Deth, 1995), and it has been found to be the most powerful predictor of higher levels of moral development (Rest, 1986).

\subsubsection{Educational level of employees}

Finally, we controlled for the educational level of employees, which is common in analyses of ventures' complexity and opacity levels because it indicates the competence and specialization needed to carry out venture tasks. The more complex and opaque a venture is, the more difficult it is for banks to assess the venture, so bootstrapping may become the only viable option in such cases (Smith, 2009).

\section{Results}

Table 1 presents all the means, standard deviations, and correlations for the variables that were included in this study. The low correlations between the independent variables suggest that multicollinearity was not an issue (Aiken et al., 1991).

Table 2 reports the results of the regression models used to evaluate the framework and the hypotheses regarding the necessity to engage in bootstrapping. Overall, the results provide solid support for the claims in Hypotheses 1 and 2, and illuminate the explorative question. The results support the claim that relationship-based lending decreases the necessity to bootstrap, whereas transaction-based lending increases the necessity to bootstrap $(\beta=-0.232, \mathrm{p}<0.05)$. The model also supports the argument that women have a higher need to bootstrap $(\beta=-0.421, \mathrm{p}<0.001)$. Finally, the results further establish the positive influence of banks' dominant use of relationship-based lending on gender with regard to the necessity to bootstrap $(\beta=0.470, p<0.001)$. Specifically,

Table 2

Regression analysis. Dependent variable: necessity to bootstrap.

\begin{tabular}{|c|c|c|c|c|c|c|}
\hline & \multicolumn{6}{|c|}{ Dependent variable: necessity to bootstrap } \\
\hline & \multicolumn{2}{|l|}{ Base model (M1) } & \multirow[t]{3}{*}{ Independent effects (M2) } & \multicolumn{2}{|l|}{ Interaction } & \multirow[b]{4}{*}{ Standard errors } \\
\hline & \multirow[b]{3}{*}{ Coefficient } & \multirow[b]{3}{*}{ Standard errors } & & effects & & \\
\hline & & & & (M3) & & \\
\hline & & & Coefficient & Standard errors & Coefficient & \\
\hline Constant & $2.124^{* * * *}$ & 0.219 & $2.096^{* * * *}$ & 0.223 & $2.253^{* * * *}$ & 0.201 \\
\hline Age of the firm (years) & -0.074 & 0.068 & -0.068 & 0.068 & -0.084 & 0.060 \\
\hline Number of employees & -0.029 & 0.063 & -0.067 & 0.062 & -0.039 & 0.056 \\
\hline Educational level of CEO & 0.149 & 0.081 & 0.075 & 0.083 & 0.113 & 0.074 \\
\hline Educational level of employees & $-0.184^{\dagger}$ & 0.057 & -0.172 & 0.058 & $-0.199^{*}$ & 0.052 \\
\hline Capital need & $-0.314^{* * *}$ & 0.066 & $-0.376^{* * * *}$ & 0.071 & $-0.387^{* * * *}$ & 0.063 \\
\hline Gender & & & $-0.232^{*}$ & 0.070 & $-0.421^{* * * *}$ & 0.068 \\
\hline $\begin{array}{l}\text { Banks transaction/relation model } \\
\text { dominance }\end{array}$ & & & $-0.292^{* * *}$ & 0.076 & -0.232 & 0.069 \\
\hline Gender x banks' decision-making models & & & & & $0.470^{* * * *}$ & 0.056 \\
\hline $\mathrm{R}^{2}$ & $0.128^{* * *}$ & & $0.216^{* * * *}$ & & $0.384^{* * * * *}$ & \\
\hline Adjusted $\mathrm{R}^{2}$ & $0.091^{* * *}$ & & $0.166^{* * * *}$ & & $0.338^{* * *}$ & \\
\hline
\end{tabular}

\footnotetext{
${ }^{+} \mathrm{p}<0.10$.

* $\mathrm{p}<0.05$.

** $\mathrm{p}<0.01$.

$\mathrm{p}<0.001$.
} 


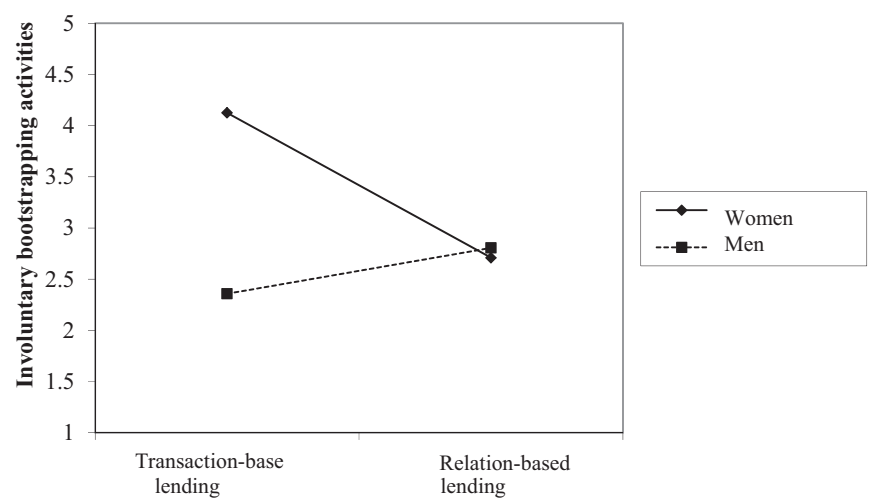

Fig. 1. Moderating effect of gender and banks' decision model on necessity to bootstrap.

Fig. 1 illustrates that women entrepreneurs confronted by banks dominated by transaction-based lending need to bootstrap the most, whereas men entrepreneurs need to bootstrap the least.

\subsection{Concluding remarks}

We show that banks' decision models determine entrepreneurs' engagement in informal economic activities and that women engage in such activities to a higher extent than men. We explore these results further using Shaw and McKay's (1942) theory of social disorganization, which has been used to provide strong theoretical and empirical explanations for regional differences in criminal activities and other deviant or illegitimate behaviors (Lilly et al., 2002; Donaldson and Dunfee, 1994). Inspired by this theory, we explore the inability of formal economic institutions to realize the value of enterprising individuals seeking financing (Kornhauser, 1978; Bursik, 1984), potentially leading entrepreneurs to increase their involuntary informal economy activities. The theory includes the assumption that structural barriers-in our case banks' decision-making models-impede the development of formal and informal ties that promote entrepreneurs' ability to solve their financial problems. The theory suggests that engagement in informal economic activities is a consequence of local formal economic institutions. Whereas more socially organized contexts are better able to establish effective networks to support entrepreneurship, as expected in relationship-based lending, structural factors in socially disorganized contexts tend to inhibit socialization, as expected in transaction-based lending.

We also explore the moderating effect of gender in the relationship between banks' decision models and entrepreneurs' engagement in involuntary bootstrapping. Although it has been argued that the centralization of financing decision making could improve conditions for women entrepreneurs (Kessler, 2016), we show that this model may actually lead to women entrepreneurs being placed outside the formal economy and developing a need to engage in borderline resource acquisition through involuntary bootstrapping. Although we suggest that these findings relate to gender stereotyping in access to finance, we may gain further insight by drawing on social disorganization theory to explain why informal economic activities may be used more or less by women and men entrepreneurs operating in various formal economic contexts. From the social disorganization perspective, gender is expected to moderate the relationship between banks' decision-making models and entrepreneurs' engagement in the informal economy. In fact, research on social disorganization theory has shown a consistent relationship between economic inequality and high crime rates (Boggess and Hipp, 2010; Krivo and Peterson, 1996). Based on research on street crime, unequal access to formal economic institutions may increase illegal or illegitimate activities when entrepreneurs compare themselves with others in their context who are more affluent or have more resources. As a consequence of this perceived injustice or strain, criminal activities may increase; that is, those being discriminated against are more likely to engage in informal economy activities (cf. Hipp, 2010). Based on Shaw and McKay's (1942) work on how crime activities occur when formal economic institutions neglect enterprising individuals, we show how transaction based lending leads to gender biases that impact entrepreneurs' ability to finance their ventures. Drawing upon their work, we found that women entrepreneurs with weak relationships with their bankers demonstrate higher necessity to bootstrap, indicating that unequal access to finance can increase informal economic activities. When women entrepreneurs compare themselves with men in their context and realize the discrepancy in access to finance, they act to compensate for this bias.

Our results have several implications. First, banks may need to revisit their decision models to strive for equal opportunities when financing entrepreneurship. Second, women entrepreneurs need to be selective when choosing a bank, consider the bank's decision model, and build relationships with the bankers in an attempt to overcome stereotyping and gender-biased access to financing. Third, for bank policy, this study highlights the need for equality measurements to support change in the banking sector and government involvement in the entrepreneurial process to stimulate growth and innovation on equal terms for men and women. Further, research should more rigorously explore the nature of the decision processes that determine which entrepreneurs may or may not access bank financing. Given that two decision models dominate these processes and are associated with gender bias in different ways in terms of necessitating engagement in informal economic activities, we need to know more about what is lost-as well as how and why this loss occurs-when banks adopt transaction-based lending models. 


\section{Declarations of interest}

None.

\section{References}

Aiken, L.S., West, S.G., Reno, R.R., 1991. Multiple regression: testing and interpreting interactions. Sage, London: UK.

Alsos, G.A., Isaksen, E.J., Ljunggren, E., 2006. New venture financing and subsequent business growth in men-and women-led businesses. Entrep. Theory Pract. 30 (5), 667-686.

Baker, T., Nelson, R.E., 2005. Creating something from nothing: resource construction through entrepreneurial bricolage. Adm. Sci. Q. 50 (3), 329-366.

Banaji, M.R., Hardin, C.D., 1996. Automatic stereotyping. Psychol. Sci. 7 (3), 136-141.

Baron, R.A., Markman, G.D., 2003. Beyond social capital: the role of entrepreneurs' social competence in their financial success. J. Bus. Ventur. 18 (1), 41-60.

Beck, T., Demirguc-Kunt, A., 2006. Small and medium-size enterprises: access to finance as a growth constraint. J. Bank. Finance 30 (11), $2931-2943$.

Berger, A.N., Udell, G.F., 2002. Small business credit availability and relationship lending: the importance of bank organisational structure. Econ. J. 112 (477).

Berger, A.N., Udell, G.F., 2006. A more complete conceptual framework for SME finance. J. Bank. Financ. 30 (11), $2945-2966$.

Bhide, A., 1992. Bootstrap finance: the art of start-ups. Harv. Bus. Rev. 70 (6), 109-117.

Black, S.E., Strahan, P.E., 2002. Entrepreneurship and bank credit availability. J. Financ. 57 (6), 2807-2833.

Boggess, L.N., Hipp, J.R., 2010. Violent crime, residential instability and mobility: does the relationship differ in minority neighborhoods? J. Quant. Criminol. 26 (3), $351-370$.

Brush, C.G., Carter, N.M., Gatewood, E.J., Greene, P.G., Hart, M.M., 2006. The use of bootstrapping by women entrepreneurs in positioning for growth. Venture Capital 8 (1), 15-31.

Bursik, R.J., Jr, 1984. Urban dynamics and ecological studies of delinquency. Soc. Forces 63 (2), $393-413$.

Carter, N., Brush, C., Greene, P., Gatewood, E., Hart, M., 2003. Women entrepreneurs who break through to equity financing: the influence of human, social and financial capital. Ventur. Cap. Int. J. Entrep. Financ. 5 (1), 1-28.

Carter, R., Van Auken, H., 2005. Bootstrap financing and owner's perceptions of their business constraints and opportunities. Entrep. Reg. Dev. 17 (2), $129-144$. Castells, M., Portes, A., 1989. World underneath: the origins, dynamics, and effects of the informal economy. Informal Econ.: Stud. Adv. Less Dev. Ctries. 12.

Centeno, M.A., Portes, A., 2006. The informal economy in the shadow of the state. Shad. Polit. Action Informal Econ. Lat. Am., 23-48.

Chamlin, M.B., Cochran, J.K., 1995. Assessing Messner and Rosenfeld's institutional anomie theory: a partial test. Criminology 33 (3), $411-429$.

Chandler, G.N., Lyon, D.W., 2001. Issues of research design and construct measurement in entrepreneurship research: the past decade. Entrep. Theory Pract. 25 (4), $101-113$.

Coleman, S., 2004. Access to debt capital for small women- and minority-owned firms: does educational attainment have an impact? J. Dev. Entrep. 9 (2), $127-144$.

Cotugno, M., Monferrà, S., Sampagnaro, G., 2013. Relationship lending, hierarchical distance and credit tightening: evidence from the financial crisis. J. Bank. Financ. 37 (5), 1372-1385.

De Castro, J.O., Balkin, D.B., Shepherd, D.A., 2008. Can entrepreneurial firms benefit from product piracy? J. Bus. Ventur. 23, 75-90.

Donaldson, T., Dunfee, T.W., 1994. Toward a unified conception of business ethics: integrative social contracts theory. Acad. Manag. Rev. 19 (2), $252-284$.

Ebben, J., Johnson, A., 2006. Bootstrapping in small firms: an empirical analysis of change over time. J. Bus. Ventur. 21 (6), $851-865$.

Ebben, J.J., 2009. Bootstrapping and the financial condition of small firms. Int. J. Entrep. Behav. Res. 15 (4), $346-363$.

Fiske, S.T., 2000. Stereotyping, prejudice, and discrimination at the seam between the centuries: evolution, culture, mind, and brain. Eur. J. Social. Psychol. 30 (3), 299-322.

Freear, J., Sohl, J.E., Wetzel, W.E., Jr., 1995. Early Stage Software Ventures: what is Working and What is Not. Centre for Venture Economics, University of New Hampshire, Durham, NH.

Garud, R., Kamoe, P., 2003. Bricolage versus breakthrough: distributed and embedded agency in technology entrepreneurship. Res. Policy 32 (2), 277-300.

Gorman, G.G., Rosa, P.J., Faseruk, A., 2005. Institutional lending to knowledge-based businesses. J. Bus. Ventur. 20, 793-819.

Harrison, R.T., Mason, C.M., 1997. Entrepreneurial Growth strategies and venture performance in the software industry. Paper presented at the 17th Annual Babson College Entrepreneurship Research Conference, Boston, MA.

Harrison, R.T., Mason, C.M., Girling, P., 2004. Financial bootstrapping and venture development in the software industry. Entrep. Reg. Dev. 16 (4), $307-333$.

Hauswald, R., Marquez, R., 2006. Competition and strategic information acquisition in credit markets. Rev. Financ. Stud. 19 (3), $967-1000$.

Haynes, G.W., Haynes, D.C., 1999. The debt structure of small businesses owned by women in 1987 and 1993. J. Small Bus. Manag. 37 (2).

Heilman, M.E., 2001. Description and prescription: how gender stereotypes prevent women's ascent up the organizational ladder. J. Social. Issues 51 (4), 657-674.

Hipp, J.R., 2010. A dynamic view of neighborhoods: the reciprocal relationship between crime and neighborhood structural characteristics. Soc. Probl. 57 (2), $205-230$.

Holthausen, R.W., Leftwich, R.W., 1983. The economic consequences of accounting choice implications of costly contracting and monitoring. J. Account. Econ. 5, $77-117$.

Kanze, D., Huang, L., Conley, M.A., Higgins, E.T., 2017. We ask men to win \& women not to lose: Closing the gender gap in startup funding. Acad. Manag. J..

Kessler, S. (2016), Women data not humans guide VC funding, more women win, Fast Company, 17 March, available at: www.fastcompany.com/3057844/whendata-not-humans-guide-vcfunding- more-women-win.

Khavul, S., Bruton, G.D., Wood, E., 2009. Informal family business in Africa. Entrep. Theory Pract. 33 (6), $1219-1238$.

Kornhauser, R.R., 1978. Social Sources of Delinquency: An Appraisal of Analytic Models. University of Chicago Press, Chicago.

Krivo, L.J., Peterson, R.D., 1996. Extremely disadvantaged neighborhoods and urban crime. Social. Forces 75 (2), $619-648$.

Lilly, J.R., Cullen, F.T., Ball, R.A., 2002. Criminological theory: Crime and consequences. Thousand Oaks.

Malmström, M., 2014. Typologies of bootstrap financing behavior in small ventures. Venture Cap. 16 (1), $27-50$.

Malmström, M., Johansson, J., Wincent, J., 2015. Cognitive constructions of low-profit and high-profit business models: A repertory grid study of serial entrepreneurs. Entrepreneurship Theory Practice 39 (5), 1083-1109.

Malmström, M., Johansson, J., Wincent, J., 2017a. Gender stereotypes and venture support decisions: how governmental venture capitalists socially construct entrepreneurs' potential. Entrepreneurship Theory and Practice 41 (5), 833-860.

Malmström, M., Johansson, J., Wincent, J., 2017b. We recorded VCs' conversations and analyzed how differently they talk about female entrepreneurs. Harvard Business Review.

Malmström, M., Voitkane, A., Johansson, J., Wincent, J., 2018. When stereotypical gender notions see the light of day, will they burst? Venture capitalists' gender constructions versus venturing performance facts. J. Bus. Venturing Insights 9, 32-38.

Merton, R.K., 1968. Social Theory and Social Structure. The Free Press, New York.

Messner, S.F., Rosenfeld, R., 1997. Political restraint of the market and levels of criminal homicide: a cross-national application of institutional-anomie theory. Soc. Forces 75 (4), 1393-1416.

Messner, S.F., Rosenfeld, R., 2001. An institutional-anomie theory of crime. Explain. Crim. Crime, 151-160.

Morris, M., Schindehutte, M., Allen, J., 2005. The entrepreneur's business model: toward a unified perspective. J. Bus. Res. 58 , $726-735$.

Neeley, L., Van Auken, H., 2010. Differences between female and male entrepreneurs' use of bootstrap financing. J. Dev. Entrepreneurship 15 (1), 19-34.

Nichter, S., Goldmark, L., 2009. Small firm growth in developing countries. World Dev. 37 (9), $1453-1464$.

O'Gorman, C., Terjesen, S., 2006. Financing the Celtic tigress: venture financing and informal investment in Ireland. Ventur. Capital. 8 (1), $69-88$. 
Portes, A., Haller, W., 2005. The informal economy. In: Smelser, N.J., Swedberg, R. (Eds.), The Handbook of Economic Sociology2nd ed. Princeton University Press and Russell Sage Foundation, Princeton, NJ, 403-425.

Rest, J.R., 1986. Moral development: Advances in research and theory.

Ridgeway, C.L., 2001. Gender, status, and leadership. J. Social. Issues 57 (4), 637-655.

Rutherford, M.W., Buller, P.F., 2007. Searching for the legitimacy threshold. J. Manag. Inq. 16 (1), 78-92.

Shafer, S.M., Smith, H.J., Linder, J.C., 2005. The power of business models. Bus. Horiz. 48 (3), 199-207.

Shaw, C.R., McKay, H.D., 1942. Juvenile delinquency and urban areas. Chicago, IL.

Siqueira, A.C.O., Bruton, G.D., 2010. High-technology entrepreneurship in emerging economies: firm informality and contextualization of resource-based theory. IEEE Trans. Eng. Manag. 57 (1), 39-50.

Starr, J., Macmillan, I., 1990, resource cooptation via social contracting: resource acquisition strategies for new ventures. Strateg. Manag. J. 11, 79-92.

Van Auken, H., 2003. An empirical investigation of bootstrap financing among small firms. J. Small Bus. Strat. 14 (2), 22.

Van Auken, H., 2005. Differences in the usage of bootstrap financing among technology-based versus nontechnology-based firms. J. Small Bus. Manag. 43 (1), 93-103.

Van Auken, H., Neeley, L., 1996. Evidence of bootstrap financing among small start-up firms. Entrep. Small Bus. Financ. 5 (3), $235-249$.

Van Deth, J.W., 1995. A macro setting for micro politics. In: Van Deth, J.W., Scarbrough, E. (Eds.), The Impact of Values. Oxford University Press, New York, $48-75$.

Vanacker, T., Manigart, S., Meuleman, M., Sels, L., 2011. A longitudinal study on the relationship between financial bootstrapping and new venture growth. Entrep. Reg. Dev. 23 (9-10), 681-705.

Webb, J.W., Tihanyi, L., Ireland, R.D., Sirmon, D.G., 2009. You say illegal, I say legitimate: entrepreneurship in the informal economy. Acad. Manag. Rev. 34, 492-510.

Webb, J.W., Bruton, G.D., Tihanyi, L., Ireland, R.D., 2013. Research on entrepreneurship in the informal economy: framing a research agenda. J. Bus. Ventur. 28 (5), 598-614.

Westphal, J.D., Boivie, S., Chng, M., Han, D., 2006. The strategic impetus for social network ties: reconstituting broken CEO friendship ties. Strateg. Manag. J. 27 (5), 425-445.

Winborg, J., 2009. Use of financial bootstrapping in new businesses: a question of last resort? Ventur. Capital. 11 (1), $71-83$.

Winborg, J., Landstrom, H., 2000. Financial bootstrapping in small businesses: Examining small business managers' resource acquisition behaviors. J. Bus. Ventur. 16 (3), 235-254.

Winborg, J., Landström, H., 2001. Financial bootstrapping in small businesses: Examining small business managers' resource acquisition behaviors. J. Bus. Ventur. 16 (3), 235-254.

Winborg, J., Landström, H., 1997. Financial bootstrapping in small businesses-a resource-based view on small business finance.”. In: Reynolds, P.D., Bygrave, W.D., Carter, N.M., Davidsson, P., Gartner, W.B., Mason, C.M., McDougall, P.P. (Eds.), Frontiers of Entrepreneurship Research. Center for Entrepreneurial Studies, Babson College, Wellesley, MA, 471-485. 